\title{
Import Competition and Firm Markups in the Food Industry
}

\author{
Daniele Curzi ${ }^{\mathrm{a}^{*}}$, Maria Garrone ${ }^{\mathrm{b}, \mathrm{c} * *}$ and Alessandro Olper ${ }^{\mathrm{a}, \mathrm{b}}$ \\ ${ }^{(a)}$ Department of Environmental Science and Policy, University of Milan, Italy \\ (b) LICOS - Centre for Institution and Economic Performance, KU Leuven, Belgium \\ ${ }^{(c)}$ European Commission
}

\begin{abstract}
This paper assesses the relationship between import competition and firm-level markups by examining the imports of intermediate and final goods. Using a rich firm-level dataset of French food companies from 2001 to 2013, we find that, on average, increased final goods import competition (intermediate inputs) is negatively (positively) associated with firm-level markups. These results are consistent with the trade models that predict the pro-competitive effects of trade and the incomplete cost pass-through to prices. Importantly, the reduction in markups due to the pro-competitive effect of trade tends to be counterbalanced by the increase in markups induced by incomplete pass-through. Our empirical analysis uncovers considerable heterogeneity in the effects of output and input import competition on markups. Our results particularly reveal that firm size and industry market structure (i.e. concentration) are key determinants of how firmlevel markups respond to import competition.
\end{abstract}

Keywords: Firm-level markups, food industry, import competition, intermediate inputs, market structure, pass-through.

JEL: F13, L25, L66, O14, P31, P33

* Corresponding author: Daniele Curzi: daniele.curzi@unimi.it

**The opinions expressed in this paper are those of the authors and do not necessarily reflect the views of their institutions. Most of the research presented in this paper was carried out before Maria Garrone joined the European Commission, while she was a PhD candidate at KU Leuven. 
Although the impact of trade on competition and market structures is of vital importance, surprisingly only a handful of studies investigate how import competition affects the performance of food firms, such as their productivity and export activity (Chevassus-Lozza et al. 2013; Olper, Curzi, and Raimondi 2017). With the partial exception of Vancauteren (2013), there is no evidence on how firm-level markup, which measures the ability of a firm to charge prices above its marginal costs, responds to changes in import competition in the food industry. The study of how firm markups and their dynamic respond to trade integration can provide important insights into several crucial issues, such as the gains from trade, the degree of sectoral competition and the market structure (Feenstra and Weinstein 2017; Liu and Ma 2017; Arkolakis et al. 2019).

Despite the evident importance of trade openness for firm-level markups, there is little prior research analyzing the relationship between trade openness and variable markups; as noted by De Loecker et al. (2016), "several of the influential firms-heterogeneity trade models assume constant markups and by doing so, abstract away from the markup channel as a potential source of gains from trade" (p. 477). Against this background, the objective of this paper is to bring new empirical evidence, based on detailed trade and firm-level data, to analyze how the import competition of intermediates and final goods affects firm-level markups in the French food industry. To our knowledge, no empirical studies to date have explicitly investigated this relationship in this sector in any country.

Relying on the econometric methodology developed by De Loecker and Warzynski (2012) (DLW hereafter), using balance-sheet data collected by the Bureau-Van Dijk (BVD) over the 2001-2013 period, we were able to estimate firm- and time-specific markups for more than 6,500 food French companies. This allows us to study the relationship between import competition in final and intermediary products and firm-level markups while accounting for heterogeneous effects across firm and industry characteristics. 
Our main results can be summarized as follows. First, an increase in import competition of final goods (intermediate inputs) is negatively (positively) associated with firm-level markups, so that the pro-competitive effects of trade tend to be counterbalanced by the incomplete passthrough of (inputs) cost reductions to prices. Interestingly, all of these effects are strongly heterogeneous across firm characteristics (such as firm size and export status), and market structure and indicate the critical role played by market power in determining how markups respond to increased import competition.

Our paper contributes to the existing literature in several directions. This is the first paper presenting empirical evidence of the effect of import competition on markups in the food industry by distinguishing between the effects of imports of final goods and those of intermediate inputs. From this perspective, our results are consistent with recent trade models that predict a procompetitive effect of import competition on final goods (see Melitz and Ottaviano 2008; Edmond et al. 2015; Feenstra and Weinstein 2017) and an incomplete pass-through of cost reductions, which are induced by imported inputs, to prices (see De Loecker et al. 2016; Liu and Ma 2017; Weinberger 2015).

However, these average effects are further investigated by analyzing their heterogeneity across a number of salient firm and market characteristics. In particular, to study potential mechanisms driving our results, we rely on the relevant international trade and industrial organization (I-O) literature that analyzes how firms react to exogenous shocks, depending on their size, market structure and other market conditions.

In this respect, we show that the pro-competitive effect of trade does not apply to firms belonging to the upper tail of the markup distribution, which instead disproportionally raise their markups as an effect of the import competition in intermediate inputs. Evidence of this phenomenon has never been revealed in the food sector and suggests that very few firms take 
disproportional advantages from trade integration. This result is difficult to reconcile with the existing trade models, but is consistent with both the recent macro-evidence on the evolution of markups and market power (see Autor et al. 2020; De Loecker et al. 2020; De Loecker and Eeckhout 2018) and the phenomenon of more dominant firms exercising their buyer power over their input suppliers (Weldegebriel 2004).

Taken together, all these findings allow the development of a comprehensive overview of how output and input import competition affect firms' markups in the food industry differently, an issue that has never been explored in such detail within the agricultural economics literature. Although the analysis focuses on the French food industry, our results, with some caveats, can apply to a more general context. The elements that are core to our study, namely the increasing import competition and the market structure of the food industry, are quite common, especially in most developed countries, although each country has its own peculiarities.

${ }^{1}$ Moreover, the market structure of the French food sector, as well as in the other OECD countries, has witnessed a significant increase in the level of market concentration over time (Rogers 2001; Sexton 2013; McCorriston 2002; McCorriston 2011). Consequently, the competition in these markets has been altered by the rising market power exercised by a few firms. As we discuss in detail in this paper, market power (either in the form of seller or buyer power) is a core determinant of how both input and output import competition affect a firm's markup formation.

The paper is structured as follows. The following section reviews the related literature on markups and trade openness, linking them with the key insights from the literature on incomplete pass-through in the food chain. We then present the method applied for the estimation of firm markups and the construction of the indices of output and input import competition. To follow, we introduce our identification strategy and discuss the potential mechanisms through which the 
import competition of final and intermediate goods may affect firm-level markups. We also discuss and address the potential endogeneity issues associated with this analysis. We then describe the datasets and report the descriptive statistics. Finally, we discuss the econometric results and present our main conclusions.

\section{Background and Related Literature}

The theoretical and empirical literature on the effect of trade liberalization on firm performance is large, encompasses different economic fields, and goes back at least to Adam Smith's idea that competition works in the general interest. The early literature focused mainly on industry and firm-level productivity growth. More recently, the emphasis has gradually shifted to other measures of performance and, notably, to markups. This is because, as we will explain further in this section, markups represent a crucial indicator allowing the distribution of the gains from trade to be determined. In what follows, we review the more recent trade and industrial organization literature that focuses explicitly on how external (trade) shocks, by altering market conditions, prices and firm costs, affect changes in firms' behavior, as summarized by their markups.

\section{Empirical Literature on Trade Openness and Markups}

Opening up an economy exposes domestic firms to higher competition, which forces the least productive ones to exit the market, while simultaneously leading more productive firms to improve, grow (Melitz, 2003), and benefit from an expansion of imports of (new) input varieties (Amiti and Konings 2007; Goldberg et al. 2010; Topolava and Khandelwal 2011).

The early empirical literature on firm-level markups primarily examined how trade liberalization affects the level of competition in final good markets and focused on one welfareenhancing mechanism, i.e. the so-called pro-competitive effect of trade liberalization. Opening 
up to trade heightens import competition and hence forces firms to lower their markups, a mechanism Levinsohn (1993) called the "imports-as-market-discipline hypothesis". As a result, both consumer surplus and allocative efficiency increase (Brandt et al. 2017). These procompetitive effects were largely documented as a result of increased trade integration and the trade reforms of countries. ${ }^{2}$ However, other studies report mixed effects of trade integration on markups. $^{3}$

In the last decade or so, the emphasis has shifted from the impact of import competition in the final goods market to those coming from increasing import competition in the intermediate inputs market (Amiti and Konings 2007). While most studies emphasize how imported intermediates play an important role in determining firm performance, such as productivity, ${ }^{4}$ the paper by De Loecker et al. (2016) was the first in the trade literature to investigate the separate effects of input and output tariff liberalization on estimated firm-level markups. ${ }^{5}$ They provide evidence that the pro-competitive effect of output tariff reduction might be largely counterbalanced by the cost-reducing effect of having increased access to imported intermediate inputs. Their findings show that due to the incomplete pass-through of costs to consumer prices, the trade liberalization of intermediate inputs led to an increase in firm markups in the case of India's trade reform. Similar results were found in the case of China's WTO accession (e.g., Brandt et al. 2017). ${ }^{6}$ Our paper is closely related to this strand of literature. Our empirical analysis emphasizes, in particular, the importance of controlling for import competition in both final and intermediate goods on markups, as they are likely to have contrasting effects. If one neglects the input channel, the assessment of the welfare implications from higher trade exposure will miss a crucial aspect, which takes the form of lower-priced intermediates.

Based on these considerations, the aim of this paper is, first, to examine whether the imports of final and intermediate goods affect firm-level markups in the EU food industry 
differently. Second, we test whether these potential contrasting effects are heterogeneous across firm and sector characteristics.

\section{Cost Pass-through, Markups and International Trade}

Understanding the relationship between markups and international trade shocks, such as exchange rate fluctuations, trade liberalization episodes, and globalization, is generally critical for international economists. The evidence from the literature seems to converge on the fact that changes in marginal costs due to any trade-related event are only partially reflected in firms' (final) prices. This mechanism is known as the incomplete pass-through of cost-shocks into firm prices (Arkolakis and Morlacco 2017). One of the main reasons behind this incomplete passthrough is that heterogeneous firms charge variable markups. ${ }^{7}$ If one considers markups as constant, then the pass-through is complete, and so any change in costs is fully transmitted to prices. However, if the demand elasticity is increasing in price, then, for instance, an increase in marginal costs (which leads to a price growth) will lead to an increase in the price elasticity of the demand and thus to a reduction in the markup. In this scenario, an increase in costs is not fully reflected in prices and so pass-through is incomplete. The assumption of constant markups has prevented earlier seminal international trade models from making any assessment of the welfare effect of trade shocks affecting firms' marginal costs (De Loecker et al. 2016). As shown by Arkolakis et al. (2019), when considering trade liberalization, welfare gains can change significantly if one assumes constant markups or not. In this paper, we rely on the DLW (2012) approach to estimate firm-level markups, although we do not observe direct firm-level price and marginal cost data. By relaxing the constant markups assumption, as suggested by the above literature, our analysis will provide some new insights on the distribution of gains from trade resulting from increased import competition in the food sector. 
A growing body of empirical evidence on how markups could be an additional source of gains from trade has motivated the recent theoretical research in international trade to relax the restrictive assumptions on constant markups of previous trade models. ${ }^{8}$ Some of these recent theoretical models, such as Melitz and Ottaviano (2008) and Arkolakis et al. (2019), have introduced variable markups by moving away from Constant Elasticity of Substitution (CES) preferences, while maintaining the monopolistic competition setting. Other studies have assumed oligopolistic competition while maintaining the assumption of CES preferences, such as Edmond, Midrigan, and Xu (2015). Both Melitz and Ottaviano (2008) and Edmond, Midrigan, and $\mathrm{Xu}(2015)$ generate a rich set of predictions on the effect of trade liberalization on firm-level markups.

Arkolakis et al. (2019) investigate a broader class of variable markup models and find pro-competitive effects of trade to be "elusive", as, depending on the degree of (home vs. foreign) cross-country sectoral differences in productivity, markups of foreign producers may also increase, leading to welfare gains moving in the opposite direction. ${ }^{9}$ More recently, Liu and Ma (2017) extended the theoretical model of Melitz and Ottaviano (2008) to analyze how changes in import tariffs affect firms' markups, by allowing firms to source inputs from foreign markets. The authors derive a number of predictions on the relationship between output and input tariff reduction, namely: $i$. a reduction in output tariffs reduces the markups of all firms; $i$. a reduction in input tariffs reduces the markups for non-importing firms, while the markups for those importers that obtain a large enough reduction of marginal costs are increased; and iii. the markups of importers increase on average, and more so in less competitive industries.

\section{Pass-through and Markups: Structural Models vs. Production Function Approach}

Cost pass-through has been the subject of several studies in different economic fields (Li 2018). ${ }^{10}$ This literature mainly used two approaches to investigate the relationship between pass-through 
and markups: the structural (demand-based) approach, and the production function approach. In the former case, assumptions are made with respect to the market demand and competitive structures, which are then considered together to retrieve the firm-level performance. While the structural (demand-base) approach has unquestionable advantages, such as a better consideration of heterogeneity and product differentiation, these come at the expense of the imposition of some quite restrictive assumptions. For this reason, a structural approach can be considered more suited to case studies of particular products/industries, where the knowledge of these detailed parameters can lead to setting the appropriate structure but is less suitable to large cross-sectoral analyses, as in the present study (De Loecker and Goldberg 2014).

Alternatively, as suggested by De Loecker (2010) and De Loecker and Goldberg (2014), the measures of firms' performance can be estimated using a production function approach. Within this framework, productivity and markups can be measured without relying on particular assumptions on the underlying demand and market structure, as is necessary in the demandoriented structural approach dealing with imperfect competition. In this setting, measures of firms' performance are usually retrieved as residual from a regression of sales on input expenditures. However, only under a set of restrictive assumptions can the obtained residual be considered an actual measure of physical productivity. These residuals typically capture more than productivity. Within this framework, DLW (2012) developed a methodology to estimate markups by relying on a production function approach.

In this paper, we follow the production function framework to estimate firm-level markups, and we specifically rely on the DLW (2012) methodology. As highlighted by the relevant literature above, this approach is particularly suitable in our case, as we focus on the whole food and drink industry, which encompasses a number of highly heterogeneous subsectors. As described in detail below, after computing a measure of profitability through a production 
function approach, we can therefore estimate how output and input import competition impact firm-level markups in the food sector.

When dealing with pass-through and markups in the food sector, the presence of noncompetitive market structures can be one of the main determinants of incomplete pass-through (McCorriston 2002; Meyer and von Cramon-Taubadel 2004; Lloyd 2017). ${ }^{11}$ This is especially true in the EU, the US, and in OECD countries in general, where both the food manufacturing and retailing sectors are increasingly concentrated (McCorriston 2002; Sexton 2013; McCorriston 2011; Lopez, He, and Azzam 2018). In this setting, a great deal of this literature has attributed the occurrence of such incomplete pass-through to the market power exerted by a few firms in imperfectly competitive food sectors (Weldegebriel 2004). This may be due, for instance, to the existence of buyer power within the agricultural and food marketing system. As highlighted by Weldegebriel (2004), if along the food chain, food-processing and retailing sectors exert monopsony/oligopsony power over the agricultural suppliers of raw agricultural products, their buyer power may offset the potential reduction of markups due to an increase in the price of intermediate inputs. Moreover, within this framework, as shown by McCorriston and Sheldon (1996), incomplete pass-through may be further exacerbated by the existence of successive oligopolies characterizing the food manufacturing and retailing stages, and thus by the market power exerted at each stage and at the following stages.

\section{Methodology}

\section{Firm-level Markups}

The estimation of markups has a long history in the industrial organization literature. In his seminal work, Hall $(1986 ; 1988 ; 1990)$ proposes a simple method, the so-called production function approach, to estimate markups by comparing the growth rates of the outputs to those of 
inputs and exploiting the fact that, under imperfect competition, the costs and revenue shares of inputs differ. ${ }^{12}$ To deal with potential endogeneity problems when estimating the production function, Roeger (1995) extended Hall's methodology and developed a method which exploits a variation in the primal and dual Solow residual to derive a consistent estimate of markups. However, a major shortcoming of these previous applications of the production function approach is that they only generate estimates for the average sector-specific markup in the sample.

Building on Hall's work, DLW (2012) propose a flexible approach for markup estimation, which provides an empirical framework to obtain firm-level markups. They rely on the assumption of standard cost minimization for variable inputs free of adjustment costs and relate the output elasticity of an input to the share of that input's expenditure in total sales and firms' markups. Exploiting the insights of Olley and Pakes (1996), Levinsohn and Petrin (2003) and Ackerberg, Caves, and Frazer (2006) (ACF hereafter), they employ a two-step procedure to address simultaneity problems and control for unobserved productivity shocks using a control variable in the estimation of the production function and the output elasticities.

The DLW method has two main advantages. First, it allows us to estimate firm- and timespecific markups without making assumptions about any particular consumer demand structure or any specific price setting model, while simultaneously dealing with the econometric issues of production function coefficients. Second, it requires production data that are easily available from firms' accounting datasets. ${ }^{13}$

Given these advantages, we closely follow the DLW (2012) method to estimate firm markups and further refine our estimation technique by explicitly allowing for endogenous productivity processes, such as learning by exporting and importing, i.e. allowing other firm- 
level actions to affect future productivity, namely our indices of import competition and a firm's

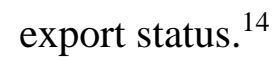

The inclusion of the export status allows us to control for the potential productivity improvements that are due to firms' participation in the export market (De Loecker and Warzynski 2012). This point is of particular importance for our study, as it is well-known that export premium often leads exporting firms to upgrade their product quality (Kugler and Verhoogen 2008; Hallak and Sivadasan 2009) and charge higher prices when targeting richer and more distant markets (Manova and Zhang 2012). As suggested by Manova and Zhang (2012), these differences in prices between exporters and non-exporters may then be considered when estimating productivity and markups. Note that the data on export participation is available in the Amadeus database for very few EU food industries (and countries), among which the French food industry was the largest in the EU.

It is worth mentioning that, given the high degree of heterogeneity of the production processes associated with the various activities of the food industry (e.g., production of meat or fish products, the dairy sector, the wine sector, etc.), we avoid relying on functional forms that make strong restrictive assumptions about the production technology, such as the fixed proportion function (Leontief) and the Cobb-Douglas (CD) function. ${ }^{15}$ As a result, in our paper, we choose to adopt a translog (TL) gross output production function of labor, capital and material costs because of its flexible functional form. We formally describe the main steps to derive and define markups and output elasticities in the Additional Material Section A.

\section{Measuring Output and Input Import Competition}

Foreign import competition can be distinguished between output and input competition. Output import competition relates to final good markets and competition from foreign firms operating within the same industry as domestic firms. On the other hand, input import competition 
considers imported intermediate inputs. Therefore, it does not have a direct impact on sectoral competition, but it captures the input composition of each sector coming from foreign firms.

Following Acemoglu et al. (2016), the output import competition is measured as follows:

$$
\Delta I C_{j t}^{\text {output }}=\frac{\text { simport }_{j t}}{\text { production }_{j, 2001}+\text { import }_{j, 2001}-\text { export }_{j, 2001}}
$$

where $\Delta I C_{j t}^{\text {output }}$ represents the change in import competition in sector $j$, between time $t$ and $t-1$. import $_{j t}$ is the annual change in the import level in sector $j$. The denominator captures the initial absorption and is given by the sum of the value of the domestic production and total imports from the world, minus total exports, in sector $j$ in the base (initial) year 2001.

The input import competition quantifies the incidence of foreign suppliers of input $k$ in industry $j$. This index is measured, following Acemoglu et al. (2016) and Ackerberg, Barattieri, and Rungi (2014), as the weighted average of the output import competition of its inputs, as follows:

$$
\Delta I C_{j t}^{\text {input }}=\sum_{k \in j} a_{k j} \Delta I C_{j t}^{\text {output* }}
$$

where the weight $a_{k j}$ is the value share of each input used by industry $j$ from industry $k$ of the total inputs utilized by industry $j$, while $\Delta I C_{j t,}^{\text {output* }}$ is the annual growth of output import competition of intermediate inputs coming from industry $k$ whose goods are used as inputs in the production processes of industry $j$. It is important to note that the import competition index of intermediate inputs includes the production and trade data of those products that, at the $\mathrm{CN}$ and Prodcom 8-digit level, are classified as intermediate goods according to the Broad Economic SNA Categories (BEC) classification.

The weights $a_{k j}$ are taken from the 2007 US I-O tables from the Bureau of Economic Analysis, as France's I-O table lacks an adequate level of disaggregation. Indeed, a major 
methodological challenge in testing this relationship in the EU is that input output (I-O) tables at a sufficient disaggregation level are not available for this macro region or for its countries. To address the lack of detailed EU I-O tables, we follow the approach proposed by Nunn (2007) and further discussed in Nunn and Trefler (2014) and Acemoglu, Johnson, and Mitton (2009) and construct a consistent index of input firm/industry exposure to import competition, using the 2007 US I-O tables as a proxy. ${ }^{16}$ In particular, we create the interaction among products based on the 'Use table' ${ }^{17}$, which reports the value of each input of commodity $k$ used in the production of industry $j$. In line with other contributions in the literature, we use the US I-O tables as proxies for the relevant industry characteristics of other countries. As explained by Nunn and Trefler (2014), the consistency of this approach lies in the fact that "no matter where goods are produced, they still require the same inputs and in the same proportions" (p.274). The US I-O tables, therefore, provide information concerning input flows across industries, conditional on the fact that they are defined by the level of technology (Acemoglu et al. 2009).

\section{Empirical Strategy and Expectations}

\section{Markups and Import Competition}

To test whether import competition affects firm-level markups, we estimate a reduced form model, as follows:

$$
\Delta \ln \mu_{i t}=\beta_{0}+\beta_{1} \Delta I C_{j t}^{\text {output }}+\beta_{2} \Delta I C_{j t}^{\text {input }}+\alpha_{i}+\gamma_{t}+\varepsilon_{i j t}
$$

where $\Delta \ln \mu_{i t}$ is 100 times the annual log change of markups for firm $i . \Delta I C_{j t}^{\text {output }}$ and $\Delta I C_{j t}^{\text {input }}$ are 100 times the annual change in output and input import competition from the world measured at the NACE 4-digit sector level $(j)$. The time invariant unobserved firm-level heterogeneity and common time shocks are controlled for through $\alpha_{i}$ and $\gamma_{t}$, namely, the firm level and time fixed effects, respectively. Last, $\varepsilon_{i j t}$ is an iid error term. With firm-level and time fixed effects 
included, the coefficients $\beta_{1}$ and $\beta_{2}$ of our import competition indices will capture the impact of changes in sectoral import competition on the firm-level markup growth. ${ }^{18}$

In evaluating the relationship between markups and import competition, some caveats are worth noting. A critical issue relates to the endogeneity arising from measurement errors due to the use of the US I-O tables to measure import competition for intermediate inputs. As discussed in Ciccone and Papaioannou (2010) and Nunn and Trefler (2014), using industry features of a benchmark country as a proxy for the corresponding industries in other countries might introduce a standard attenuation bias due to measurement error, which, if present, will lead to a downward biased estimated coefficient. ${ }^{19}$

A second relevant concern about equation (3) relates to the simultaneity problem between our import competition indices and firm-level markups. In fact, domestic demand (and supply) shocks may lead to endogenous changes in the markups and imports of both intermediates and final goods (Acemoglu et al. 2016; Goldberg et al. 2010; Dhyne et al. 2016). To address this endogeneity concern, we rely on an instrumental variable (IV) strategy initially developed by Autor, Dorn, and Hanson (2013) and Autor et al. (2014), which is now widely used approach in the trade literature. This approach instruments the import competition variables of one country using imports of other countries, which share important similarities with the country under investigation but are not affected, at least directly, by the domestic demand shocks of that country. The identification strategy relies on the assumption that similar countries (in this case OECD high-income countries) have import demand shocks that are uncorrelated with each other but are similarly affected by (world) import competition. Following this intuition, we instrument our import competition indices as follows:

$$
\Delta I C I V_{j t}^{\text {output }}=\frac{\text { import }^{G I S}{ }_{j t}}{\text { production }_{j, 2001}+\text { import }_{j, 2001}-\text { export }_{j, 2001}}
$$


where $\Delta i m p o r t{ }^{G I S}$ represents the import growth in industry $j$ in four OECD high-income countries, namely, the US, Canada, Australia and New Zealand, while the denominator represents the initial absorption in the same industry. We choose these countries following Autor et al. (2013; 2014) and Acemoglu et al. (2016), who, to instrument US import penetration from China, have used other OECD high-income countries. ${ }^{20}$ Starting from equation (4), we build our instrument for import competition in intermediate inputs in the same vein of equation (2), as follows:

$$
\Delta I C I V_{j t}^{\text {input }}=\sum_{k \in j} a_{k j} \Delta I C I V_{j t}^{\text {output } *}
$$

where $\Delta I C I V_{j t}^{\text {output* }}$ is the annual growth of output import competition of intermediate inputs for the four selected countries.

The intuition behind the use of this IV strategy is that the food sector in France and in other high-income countries are similarly exposed to imports of intermediates and final goods. This is basically due to the gradual fall in trade costs, which is quite common in high-income importing countries. However, the key point is that import demands across high-income countries are weakly correlated. This is because a shock that, for instance, may occur in the French food sector, which leads to an endogenous change in markups and in the demand of either intermediate or final goods, is unlikely to have consequences on the import demand of other (extra-EU) highincome countries. Therefore, the use of imports of intermediate and final goods of other (extraEU) OECD high-income countries leads our instruments to be presumably positively correlated to both the French output and input import competition indices. At the same time, our instruments are unlikely to be affected by any endogenous changes in the demand in the French food sector, provided that the import demands in these high-income countries are not correlated with the import demand in France. 


\section{Expectations on the Relationship between Markups and Import Competition}

What we should expect from the direction and size of the coefficients of the output and input import competition, $\beta_{1}$ and $\beta_{2}$, in equation (3)? As discussed in the Background and Literature Review section, both types of trade integration are likely to affect firm-level markups, albeit through different channels.

To investigate the mechanism of the expected direction of the impact of import competition of final or intermediate goods on firm-level markups, it is useful to start from the theoretical expectations suggested by De Loecker and Goldberg (2014), who model price, quantity, and markups' response to changes in both output and input tariffs. Their theoretical intuition reflects two different channels, i.e., the demand channel and the cost-reduction channel, through which the output and input import competition may affect firms' markups. The authors show that an expansion of imports of final goods corresponds to the standard assumption that strengthening competition in the output-oriented trade liberalization causes the residual demand curve to become more elastic and, hence, leads to lower prices and lower markups. ${ }^{21}$ In contrast, an expansion of imports of intermediate goods causes a reduction in a firm's input costs without affecting competition in the output market; hence, the residual demand curve is not affected. In this case, it is important to notice that any change will occur not in response to a change in competition but as a result of the incomplete pass-through of the marginal cost change to the price. Depending on the extent to which costs are (incompletely) passed to prices, the new market equilibrium can be associated with higher markups and lower prices that, however, do not fully reflect the costs reduction. Evidence of a similar pattern has been provided by De Loecker et al.'s (2016) analysis of trade liberalization in India.

In line with these predictions, we expect that in estimating equation (3), $\beta_{1}$ will have a negative sign while $\beta_{2}$ will have a positive one. Note that these are average predictions concerning 
the main effects under investigation. However, as discussed in the Background and Literature Review section, these dynamics are likely to affect firms differently, especially according to their market power and, more generally, the level of competition and firm heterogeneity within each sector.

\section{Controlling for Firm and Industry Characteristics}

As discussed above, an increase in the input import competition is likely to reduce the marginal costs, which are passed through the vertical food chain from the farm-gate to food manufacturing and retailers. However, the presence of market power in the downstream sectors often dampens the pass-through. This argument is consistent with the predictions in De Loecker and Goldberg (2014) and the extensive literature on pass-through that relies on the estimation of structural models in imperfect competitive markets (Weyl and Fabinger 2013), as well as the evidence concerning the vertical food chain summarized in the Background and Literature Review section.

For these reasons, in our empirical analysis, we test for the heterogeneous effect of output and input import competition across different firm and industry characteristics. First, we consider the firm size, export status and top-10 markup firms. Although indirectly, these tests may provide insights on the role of market power in affecting our main results, to the extent that larger and high-markups firms can be considered as more influential firms within a market.

Second, given the key role exerted by market power on the pass-through dynamics, in our analysis, we also assess whether the market concentration, and the presence of market power, is a driver of our main results. With this purpose, we measure market concentration by computing a normalized Herfindahl Index $\left(H I^{N}\right)$ in each French subsector at the NACE 4-digit level. ${ }^{22}$

We generate a dummy variable, which takes the value of one for high-concentrated sectors, i.e., those with an average $H I^{N}$ falling above the $90^{\text {th }}$ percentile of the average $H I^{N}$ distribution over the period, and zero otherwise. Similarly, we build another dummy variable for 
low-concentrated sectors, which takes the value of one for sectors below the $90^{\text {th }}$ percentile, and zero otherwise. ${ }^{23}$ We then estimate equation (3) by interacting our output and input import competition indices with the high- and low-industry concentration dummy variables.

\section{Data and Descriptive Statistics}

To estimate the production coefficients, elasticities and markups, the data we use are the firmlevel balance-sheet of the French food sector for the period of 2001-2013 from the Bureau van Dijk's (BVD) Amadeus database. The BVD provides information on yearly balance sheet data for firms classified at the 4-digit level, using the NACE Rev. 2 classification. ${ }^{24}$ In particular, we retrieved the data on the turnover, total assets, material costs, total wage bill, and export revenues of each firm. All the variables used in the markup estimations are deflated using the national 2digit industry deflators. ${ }^{25}$ These estimates are used to compute our firm-level markups. In the Additional Material Section, Table A1 reports the estimated coefficients and median markups under the TL specification.

Due to the quality of the data, a fairly standard data cleaning procedure was implemented. We eliminated all observations that report zero or negative values for all production variables. This resulted in an unbalanced dataset, ${ }^{26}$ which consisted of 6,562 firms. ${ }^{27}$ Table 1 shows how the observations in our sample are distributed across the different sectors defined at the NACE 3-digit level. It also shows some descriptive statistics on the median markups in level at the NACE 3-digit level. The Bakery, Other Food Products, and Oil and Fats industries have the higher level of markups.

To compute the output and input import competition indices at the NACE 4-digit level, we used the data on production from Prodcom (Eurostat) at the 8-digit level and data from the UN Food and Agriculture Organization (FAO) for all of the agricultural input products excluded from the Prodcom database that are still strongly related to the analysis of food industry sectors. 
Regarding the trade data, we use Comext (Eurostat), at the Combined Nomenclature (CN) 8-digit level. To compute our import competition indices at a level of aggregation coherent with the classification of the firm-level data, the trade and production data are then assigned to each NACE 4-digit sector using the corresponding conversion tables. To estimate the input import exposure index, we use the $2007 \mathrm{I}-\mathrm{O}$ data from the US Bureau of Economic Analysis (BEA). ${ }^{28}$

As shown in Figure 1, the positive growth rate in trade exposure of final goods and intermediate inputs rapidly increases between 2001 and 2007, but it declines sharply after 20072009 following the global financial crisis. Note, however, that the growth rate remains positive for both indices, so that the level of competition always increases, though at different rates over time. While the growth in output trade index displays a slight increase after 2012, the growth in the input trade index continues its decline until 2013. ${ }^{29}$

An important aspect to consider in our analysis is accounting for the technological evolution of the French food industry over the period covered. Import competition could affect firm markups through a change in technology rather than a variation in markups. In Section B of the Additional Material Section, we provide evidence that this is not the case for the French food sector over the considered period.

\section{Econometric Results}

\section{Import Competition and Firm-level Markups}

Table 2 presents both the OLS and IV regression results of the relationship between changes in import competition and growth in firm-level markups. ${ }^{30}$ The OLS results (Column 1) confirm the existence of a strong negative relationship between an increase in output import competition and changes in firm-level markups, an effect that is statistically significant at the $1 \%$ level. Moving to imported intermediated inputs, the estimated effect reported in the second line of 
Column 1 is positive and significant at the $1 \%$ level, so that an increase in the input trade exposure increases the firm-level markups, a result consistent with the recent empirical evidence discussed in the Background and Literature Review section. ${ }^{31}$

As discussed above, this OLS estimate could be biased because the growth in import competition is driven partly by changes in the domestic supply and demand. Column 2 mitigates this simultaneity bias by instrumenting the observed changes in import competition with contemporaneous changes in other countries. These additional IV estimates are similar in magnitude and go in the same direction of the OLS ones. Quantitatively, a rise of 10 percentage points in output import penetration reduces firm-level markups by 1.3 percentage points, while the same 10 percentage points rise in input import competition increases markups by 2.5 percentage points.

A crucial question is now to understand the extent to which the negative effect of output import competition on firm-level markups is counterbalanced by an increase in markups due to input import competition. We can assess the economic effect by considering the average markup in our sample, which is $1.30 .^{32} \mathrm{~A}$ rise of 10 percentage points in output import competition (from IV results) by inducing a decrease of 1.2 percentage points in the average markup will reduce the average markup to 1.28 . However, the increase of 10 percentage points in input import competition, by inducing a rise of 2.5 percentage points in the average markup, will increase the average markup to 1.33 . Thus, the two effects taken together tend to offset each other, with an average final markup equal to 1.31 .

In columns 3 and 4 of Table 2, we check whether these effects are heterogeneous across firms by examining the top markup-performing firms. For this purpose, we create a timeinvariant index that captures those firms belonging to the top decile of the industry's markup distribution in the first year of the period covered. This index is then interacted with both the 
output and input import competition variables. The results show that there is a positive and significant effect of output import competition on the markup growth of the top ten companies. This suggests that the best performing firms in terms of markups are less affected by opening up to trade in final goods, as are the least performing firms, which, on average, are more likely to reduce their markups and are eventually forced to exit the market. The results also show that high-markup firms gain considerably more from a higher availability of intermediate inputs. Quantitatively, the combined effect of the rise in (output and input) import competition on the markup growth of top-performing firms is impressive. A rise by 10 percentage points in output competition increases the markups of the top-performing firms by 7.5 percentage points. Measured at the sample mean, this effect implies a markups growth from 1.64 to 1.76. Similarly, a rise by 10 percentage points in input import competition increases the markups by $12 \%$, thus increasing the average markup from 1.64 to 1.83 . Although this economic effect may appear extraordinarily large, it is actually of the same order of magnitude of the global findings reported in De Loecker, Eeckhout, and Unger (2020), who found the average firm-level markups to have changed from 1.21 to 1.61 during the period $1980-2016 .^{33}$

These findings highlight the importance of firm heterogeneity effects. Whatever the source of import competition, the top firms gain, while all other firms lose with output import competition or gain less with input import competition. The hypothesis of import competition as a market-discipline device seems to work only on average, but not homogenously across firms.

The result concerning the effect of output import competition on the top-10 markup firms may appear counterintuitive at first sight, or at least in contrast with our theoretical predictions. This is because one would expect that if import competition were likely to have an impact on firms' markups, we would see the strongest impact of this effect impacting those with the highest markups. Two distinct motivations may support the interpretation of this result. 
First, our results are consistent with the findings of De Loecker, Eeckhout, and Unger (2020) and De Loecker and Eeckhout (2018), according to which, in the past three decades, the aggregated average markup has consistently increased for the whole economy in the US and Europe. Interestingly, the authors showed that while the median value of markups remained almost unaffected, the rise in markups is almost entirely attributable to the upper tail of the markup distribution. ${ }^{34}$ As suggested by De Loecker, Eeckhout, and Unger (2020), and in accordance with Melitz (2003), higher competition leads many firms to drop out of the market. This is likely to induce a reallocation of market share from low-markup firms to high-markup firms, a mechanism at the root of the 'superstar firms' phenomenon described by Autor et al. (2020). ${ }^{35}$ Our results in columns 3 and 4 seem to be consistent with this evidence. ${ }^{36}$

Second, the positive effect induced by output import competition on the top-10 markup firms may also be motivated by pass-back dynamics, which arise when firms with higher market power exert buyer power over their intermediate suppliers. The evidence from the agricultural economics literature suggests that buyer power, perhaps even more than seller power, determines the evolution of price signals down the food chain, specifically mark-downs occurring where higher competition occurs (see Dobson, Waterson and Davies 2003; Weldegebriel 2004). From this perspective, larger and more dominant firms are likely to ask suppliers of intermediate inputs to discount prices to try to offset the reduction in markups due to the reduction in prices imposed by the increase in domestic competition. Similar unfair practices have been largely documented in the literature (see, e.g., Weldegebriel 2004; Loyd et al. 2009), and they have also recently been the subject of a regulation on unfair trading practices developed by the EU Commission (European Commission 2018). ${ }^{37}$

When we consider the effect of input import competition, the higher increase in the markups of firms belonging to the upper tail of the markup distribution can be explained by 
higher incomplete pass-through of a reduction in cost to prices in firms with higher market power. To the extent that firms with higher markups are associated with higher market power, as suggested by the aforementioned literature, this is likely to lessen the pass-through of a reduction in marginal costs to prices in the top-10 markup firms. Evidence of a similar mechanism has been highlighted by Morlacco (2019) for the French manufacturing sector. The author finds that firms with higher market power pay lower prices for imported intermediate inputs compared to other firms, thus increasing the gap in markups between them. The next section will test this interpretation more formally. ${ }^{38}$

\section{Additional Results across Firm-characteristics and Robustness Checks}

To shed further light on the heterogeneous impact of output and input import competition on firm markups, we study the effects across two additional firm dimensions, namely firm size and firm export status. We use turnover and the number of employees as a proxy for firm size. Equation (3) estimates two separate coefficients for firms falling below and above the median value of the size sample distribution. The results are presented in Table 3. Interestingly, output import competition leads to a reduction in the markups only for lower-sized firms. In contrast, the effect of input import competition is positive and significant only for higher-sized firms. These results do not change regardless of whether the turnover or the number of employees is used as the proxy for firm size.

The last two columns of Table 3 include the firm-level export status and estimate coefficients for exporting and non-exporting firms separately. ${ }^{39}$ The results are similar but less obvious than those for the firm size. An increase in the output import competition is significantly associated with a reduction in the firm markups only in non-exporting firms, though the difference with exporting firms are significant at the $10 \%$ level only. In contrast, an increase in input import competition is significantly associated with an increase in the markups only for 
exporting firms. Overall, these results are not surprising given the positive relationship between firm size and export status documented by the literature, where exporting firms are usually associated with higher productivity. The higher availability of less costly intermediate inputs can be particularly favorable to more productive firms, which can eventually charge higher markups, increasing the wedge with respect to less efficient (non-exporting) firms. ${ }^{40}$ Finally, the output import competition results may be explained not only by their higher size. Firms involved in international markets may be less sensitive to changes in competition in the domestic markets, because they also compete with foreign firms as well as domestic ones

We run different robustness checks on the results presented above. First, we consider the 2004 and 2007 EU enlargements, which significantly expanded the EU single market, and second, we control for the effect of the 2007-2009 economic crisis, which caused a worldwide downturn and contraction in trade. The results of these robustness checks are presented and discussed in Table C.3 and Table C.4 of the Additional Material Section. Our main findings suggest that the estimated effects of output and input competition on firm markups are particularly relevant when considering imports from New Member States. Moreover, our results prove to be robust when controlling for the effect of the global economic crisis that occurred in 2007-2009.

\section{Accounting for Industry Market Structure}

Understanding the price dynamics along the vertical food chain and the difference in the sectoral market structure and competition is crucial for our analysis. Our review of the literature suggests, in particular, that industries' market structure and firms' market power should play a key role in affecting the pass-through of changes in costs to firms' prices and, consequently, on the markup formation. 
Figure 2 reports the firm markup distribution in high- vs. low- concentrated sectors, as defined by the normalized Herfindahl Index. The graph clearly shows that high-concentrated sectors are characterized by higher markups, as their distributional graphs are situated at the right of their counterparts. Overall, these patterns are consistent with the literature discussed in the Background and Literature Review section, which suggest that in less competitive markets, the presence of oligopoly and oligopsony power is likely to lead to higher markups.

Table 4 formally tests whether the differences in the levels of concentration across the food manufacturing subsectors are driving the relationship between markups and import competition. Columns 1 and 2 show the results of estimating equation (3) with separate coefficients for low- and high concentrated sectors, as defined by the normalized Herfindahl index. The estimated effects of import competition on firm markups confirm our main results for both low- and high-concentrated markets. However, the magnitude of the estimated effects is found to be significantly higher in high-concentrated markets. ${ }^{41}$

The results related to output import competition are consistent with the evidence in Edmond, Midrigan, and $\mathrm{Xu}$ (2015), who highlight that increasing domestic trade exposure is particularly effective in reducing the markups in highly concentrated sectors. ${ }^{42}$ Similar evidence can be found in Vancauteren (2013), who examines the EU regulatory harmonization in the Dutch food industry and in Liu and Ma (2017), who analyze the China WTO accession. The results thus suggest that, as an effect of fiercer import competition, prices are likely to pass-back along the vertical food chain, especially in those markets characterized by more concentration, where the markups are (initially) unusually high.

Conversely, an increase in the input import competition is associated with an increase in markup, which is larger in sectors with high concentration than in those with low concentration. These results are in line with the predictions coming from the pass-through literature. As outlined 
in the Background and Literature Review section, the pass-through of a change in the costs of intermediates in imperfect competitive markets is likely to be higher where, ceteris paribus, markets are more competitive. Therefore, a reduction in firms' marginal costs due to increasing input import penetration is transmitted to a lesser extent to firms' prices in less competitive markets, where the markup increase is greater. A similar result can be found in Liu and Ma $(2017){ }^{43}$

It is worth noting that in analyzing the effect of output and input import competition on markups controlling for market structure, further endogeneity concerns may arise. This is because any measure of market structure, in our case the Herfindahl Index, and markups are likely to be endogenously determined. However, our analysis is not aimed at assessing the causal relationship between market structure and markups. As widely acknowledged in the literature, and as we show in Figure 2, the markup is usually higher in more concentrated sectors. Our objective is to analyze whether changes in the output and input import competition affect changes in markups differently according to the market structure. While acknowledging that making causal inferences about markups and market structure should be done with care due to potential endogeneity issues, we believe that our analysis is informative about how markups can change in response to increases in domestic exposure to output and input import competition.

Finally, it is worth mentioning that our results refer only to the food sector, without making any direct inference on how output and input import competition can directly affect the other sectors in the vertical food-chain. However, our findings are clearly conditioned by the structure of both the food retailing and input supply sectors, as their prices form the basis of our firms' revenues, and costs, respectively. Since we do not observe any data on these sectors, we do not to speculate on how the vertical linkages within the food chain can affect our results. ${ }^{44}$ 


\section{Conclusions}

This paper investigates how firm-level markups respond to changes in import competition in the food industry. We first measure firm-level markups for approximately 6,500 French food companies operating over the period 2001-2013. We then construct two consistent indices of output and input import competition to test their effects on firm-level markups. In doing so, we also account for potential heterogeneous effects across firm and market characteristics.

Our main results confirm the existence of pro-competitive effects of trade, which leads, on average, to a reduction in the firm-level markups when the foreign output import competition increases. However, an opposite result is found when considering the effect of input import competition, suggesting an incomplete pass-through of costs to prices. Importantly, the absolute magnitude of the latter effect is higher than the former, such that the average markup rises with deeper trade integration. Our findings, therefore, stress the importance of considering trade in intermediate inputs to assess the potential gains from higher exposure to international trade. From a welfare perspective, our results suggest that both food manufacturers and consumers gain from trade integration, although to a different extent, a result consistent with previous studies documenting the effect of the reduction of output and input tariffs in other countries (see De Loecker et al. 2016; Brandt et al. 2017). Moreover, it is worth mentioning that, although the average firm's markup may increase, this does not imply a decline in consumer welfare. There are two reasons for this. Firstly, an increase in the output import competition channel still gives a pro-competitive effect which benefits consumers. So, consumers will always gain even if firms increase their markups due to the input import competition channel. Secondly, there are other mechanisms, such as quality upgrading, long-term innovation and technological gains, through which trade integration can be welfare-enhancing for consumers (De Loecker et al. 2016; De Loecker et al. 2018). 
Interestingly, we uncovered significant heterogeneity in our results. Firms with higher markup, larger firms and exporters take advantage of the reduction of marginal costs caused by cheaper and new imported inputs, while they only partially pass these reductions of costs to the final prices. Moreover, the markups of these firms are less sensitive to an increase in import competition in final goods. We also assess whether market structure is a potential key driver of our results. Our empirical analysis reveals that the effects of output and input competition are higher in magnitude in sectors with higher concentration and, thus, lower competition.

Our findings confirm the importance, which is stressed by the recent literature (De Loecker et al. 2016; Lu and Yu 2015), of jointly analyzing input and output trade competition on firm performance in order to better understand the full impact of increased trade integration in terms of the welfare distribution and resource misallocation. However, the lack of product-level data and product/firm prices prevents us from carrying out a deeper analysis of the welfare implications of these results for the food industry. Moreover, while we find that technological change does not seem to be a crucial driver of the relationship between import competition and markups, the characteristics of our dataset do not allow us to further investigate this question. Data allowing the computation of marginal costs and the analysis of quality upgrading and innovative actions, such as new product introductions, would allow further understanding of these issues. An effort in this direction constitutes a key objective of future analyses. 


\section{References}

Acemoglu, Daron, Simon Johnson, and Todd Mitton. 2009. "Determinants of vertical integration: financial development and contracting costs." The journal of finance 64(3): 1251-1290.

Acemoglu, Daron, David Autor, David Dorn, Gordon H. Hanson, and Brendan Price. 2016. "Import Competition and the Great US Employment Sag of the 2000s." Journal of Labor Economics 34 (S1): 141-198.

Ackerberg, Daniel, Kevin Caves, and Garth Frazer. 2006. Structural identification of production functions. (2006). MPRA Paper No. 38349.

Aleksanyan, Lilia, and Jean-Pierre Huiban. 2016. "Economic and financial determinants of firm bankruptcy: evidence from the French food industry." Review of Agricultural, Food and Environmental Studies 97(2): 89-108.

Altomonte, Carlo, and Alessandro Barattieri. 2015. "Endogenous markups, international trade, and the product mix." Journal of Industry, Competition and Trade 15(3): 205-221.

Altomonte, Carlo, Alessandro Barattieri, and Armando Rungi. 2014. "Import penetration, intermediate inputs and productivity: evidence from Italian firms." Rivista Italiana degli Economisti 19(1): 45-66.

Amiti, Mary, and Jozef Konings. 2007. "Trade liberalization, intermediate inputs, and productivity: Evidence from Indonesia." American Economic Review 97(5): 1611-1638.

Arkolakis, Costas, and Monica Morlacco. 2017. Variable demand elasticity, markups, and passthrough. Workin paper manuscript, Yale University.

Arkolakis, Costas, Arnaud Costinot, Dave Donaldson, Andrés Rodriguez-Clare. 2019. "The Elusive Pro-competitive Effects of Trade." Review of Economic Studies 86: 46-80.

Autor, David, H., David Dorn, and Gordon H. Hanson. 2013. "The China syndrome: Local labor market effects of import competition in the United States." American Economic Review 103(6): 2121-68.

Autor, David H., David Dorn, Gordon H. Hanson, Jae Song. 2014. “Trade Adjustment: Workerlevel Evidence." Quarterly Journal of Economics 129(4): 1799-1860. 
Autor, David, David Dorn, Lawrence F Katz, Christina Patterson, John Van Reenen. 2020. “The Fall of the Labor Share and the Rise of Superstar Firms." The Quarterly Journal of Economics 135 (2): 645-709.

Bellone, Flora, Patrick Musso, Lionel Nesta, Frederic Warzynski. 2016. "International trade and firm-level markups when location and quality matter." Journal of Economic Geography, 16(1): 67-91.

Berry, Steven, James Levinsohn, and Ariel Pakes. 1995. "Automobile prices in market equilibrium.” Econometrica 63(4): 841-890.

Brandt, Loren, Johannes Van Biesebroeck, Luhang Wang and Yifan Zhang. 2017. "WTO Accession and Performance of Chinese Manufacturing Firms." American Economic Review 107(9): 2784-2820.

Bonnet, Celine, Pierre Dubois, Sofia B. Villas Boas and Daniel Klapper. 2013. "Empirical evidence on the role of nonlinear wholesale pricing and vertical restraints on cost passthrough." Review of Economics and Statistics, 95(2): 500-515.

Chaney, Thomas. 2008. "Distorted gravity: the intensive and extensive margins of international trade." American Economic Review 98(4): 1707-21.

Chevassus-Lozza, Emmanuelle, and Karine Latouche. 2012. "Firms, markets and trade costs: access of French exporters to European agri-food markets." European Review of Agricultural Economics 39(2): 257-288.

Ciccone, Antonio, and Elias Papaioannou. 2010. Estimating cross-industry cross-country models using benchmark industry characteristics. Working Paper of the Department of Economics and Business, UPF No. 1235.

Davies, Stephen. 1979. "Choosing between concentration indices: The iso-concentration curve." Economica 46: 67-75.

De Loecker, Jan. 2013. “Detecting learning by exporting.” American Economic Journal: Microeconomics 5(3): 1-21.

De Loecker, Jan, and Jan Eeckhout. 2018. Global Market Power. Working Paper No. 24768 available at https://www.nber.org/papers/w24768. 
De Loecker, Jan, and Pinelopi Koujianou Goldberg. 2014. "Firm performance in a global market." Annual Review of Economics 6(1): 201-227.

De Loecker, Jan, and Frederic Warzynski. 2012. "Markups and firm-level export status." American Economic Review 102(6): 2437-71.

De Loecker, Jan, Jan Eeckhout, and Gabriel Unger. 2020. "The rise of market power and the macroeconomic implications.” The Quarterly Journal of Economics 135(2): 561-644.

De Loecker, Jan, Pinelopi K. Goldberg Amit K. Khandelwal Nina Pavcnik. 2016. "Prices, Markups and Trade Reform.” Econometrica 84(2): 445-510.

Dhyne, Emmanuel, Amil Petrin, Valerie Smeets, and Frederic Warzynski. 2016. Import Competition, Productivity and Multi-Product Firms. Working Paper Research NBB No. 268.

Dobson, Paul W., Michael Waterson, and Stephen W. Davies. 2003. "The patterns and implications of increasing concentration in European food retailing." Journal of Agricultural Economics 54(1): 111-125.

Duso, Tomaso, and Florian Szücs. 2017. "Market power and heterogeneous pass-through in German electricity retail.” European Economic Review 98: 354-372.

Eaton, Jonathan, and Samuel Kortum. 2002. "Technology, geography, and trade.” Econometrica 70(5): 1741-1779.

Edmond, Chris, Virgiliu Midrigan, and Daniel Yi Xu. 2015. "Competition, markups, and the gains from international trade." American Economic Review 105(10): 3183-3221.

Feenstra, Robert C. 2018. "Restoring the product variety and pro-competitive gains from trade with heterogeneous firms and bounded productivity." Journal of International Economics 110: 16-27.

Feenstra, Robert C., and David E. Weinstein. 2010. Globalization, markups, and the US price level. Cambridge: National Bureau of Economic Research Working Paper No. w15749.

Feenstra, Robert C., and David E. Weinstein. 2017. "Globalization, markups, and US welfare.” Journal of Political Economy 125(4): 1040-1074.

Feenstra, Robert C. 2018. "Restoring the product variety and pro-competitive gains from trade with heterogeneous firms and bounded productivity." Journal of International Economics 110: 16-27. 
Goldar, Bishwanath, and Suresh Chand Aggarwal. 2005. "Trade liberalization and price-cost margin in Indian industries.” The Developing Economies 43(3): 346-373.

Goldberg, Pinelopi K., and Michael M. Knetter. 1997. “Goods Prices and Exchange Rates: What Have We Learned?". Journal of Economic Literature 35: 1243-1272.

Goldberg, Pinelopi Koujianou, and Rebecca Hellerstein. 2008. "A structural approach to explaining incomplete exchange-rate pass-through and pricing-to-market." American Economic Review 98(2): 423-29.

Goldberg, Pinelopi K., Amit K. Khandelwal, Nina Pavcnik, Petia Topalova. 2010. "Imported Intermediate Inputs and Domestic Product Growth: Evidence from India.” Quarterly Journal of Economics, 125(4): 1727-1767.

Hall, Robert E., Olivier Jean Blanchard, and R. Glenn Hubbard. 1986. "Market structure and macroeconomic fluctuations.” Brookings papers on economic activity 1986(2): 285-338.

Hall, Robert E. 1988. "The relation between price and marginal cost in US industry." Journal of political Economy 96(5): 921-947.

Hall, Robert E. 1990. “Invariance Properties of Solow's Productivity Residual.” In Diamond, P. (ed.), Growth, productivity, Unemployment: Essays to Celebrate Bob Solow's Birthday. Cambridge, MA: MIT Press, pp. 71-112.

Hallak, Juan Carlos, and Jagadeesh Sivadasan. 2009. Firms' exporting behavior under quality constraints. National Bureau of Economic Research Working Paper No. w14928.

Harrison, Ann E. 1994. "Productivity, imperfect competition and trade reform: Theory and evidence." Journal of international Economics 36(1-2): 53-73.

Hindriks, Jean, and Valerio Serse. 2019. "Heterogeneity in the tax pass-through to spirit retail prices: Evidence from Belgium.” Journal of Public Economics 176: 142-160.

Jaffe, Sonia, and E. Glen Weyl. 2013. "The first-order approach to merger analysis." American Economic Journal: Microeconomics 5(4): 188-218.

Konings, Jozef, Patrick Van Cayseele, and Frederic Warzynski. 2001. "The dynamics of industrial mark-ups in two small open economies: does national competition policy matter?”. International Journal of Industrial Organization 19(5): 841-859. 
Krishna, Pravin, and Devashish Mitra. 1998. "Trade liberalization, market discipline and productivity growth: new evidence from India." Journal of Development Economics 56(2): 447-462.

Krugman, Paul. 1980. "Scale economies, product differentiation, and the pattern of trade." The American Economic Review 70(5): 950-959.

Kugler, Maurice, and Eric Verhoogen. 2008. The quality-complementarity hypothesis: Theory and evidence from Colombia. No. w14418. National Bureau of Economic Research.

Levinsohn, James. 1993. "Testing the imports-as-market-discipline hypothesis." Journal of international Economics 35(1-2): 1-22.

Levinsohn, James, and Amil Petrin. 2003. "Estimating production functions using inputs to control for unobservables." The review of Economic Studies 70(2): 317-341.

Li, Yumin. 2018. "Incentive pass-through in the California Solar Initiative-An analysis based on third-party contracts." Energy Policy 121: 534-541.

Liu, Zhengwen, and Hong Ma. 2017. "Trade Liberalization, Market Structure, and Firm Markup: Theory and Evidence from China." Working Paper.

Lloyd, Timothy A., Steve McCorriston, Wyn C. Morgan, Anthony J. Rayner. 2006. "Food scares, market power and price transmission: the UK BSE crisis". European Review of Agricultural Economics, 33(2), 119-147.

Lloyd, Timothy A., Steve McCorriston, Wyn C. Morgan, and Habtu Weldegebriel. 2009. "Buyer power in UK food retailing: a 'first-pass' test”. Journal of Agricultural \& Food Industrial Organization, 7(1): 2-38.

Lloyd, Tim. 2017. "Forty years of price transmission research in the food industry: Insights, challenges and prospects." Journal of Agricultural Economics 68(1): 3-21.

Lopez, Rigoberto A., Xi He, and Azzeddine Azzam. 2018. "Stochastic frontier estimation of market power in the food industries." Journal of Agricultural Economics 69(1): 3-17.

Lu, Yi, and Linhui Yu. 2015. "Trade liberalization and markup dispersion: evidence from China's WTO accession.” American Economic Journal: Applied Economics 7(4): 221-53.

Manova, K. and Zhang, Z. (2012). Multi-Product Firms and Product Quality. NBER Working Paper No. 18637. 
McCorriston, Steve. 2002. "Why should imperfect competition matter to agricultural economists?". European Review of Agricultural Economics 29(3): 349-371.

McCorriston, Steve. 2011. Competition in the Food Chain. Working Paper No. 11 Transparency of Food Pricing TRANSFOP.

McCorriston, Steve, and Ian M. Sheldon. 1996. "The effects of vertical markets on trade policy reform." Oxford Economic Papers 48(4): 664-672.

Melitz, Marc J. 2003. "The impact of trade on intra-industry reallocations and aggregate industry productivity." Econometrica 71(6): 1695-1725.

Melitz, Marc J., and Gianmarco Ottaviano. 2008. "Market size, trade, and productivity." The review of economic studies 75(1): 295-316.

Meyer, Jochen, and Stephan Von Cramon-Taubadel. 2004. "Asymmetric price transmission: a survey." Journal of Agricultural Economics 55(3): 581-611.

Morlacco, Monica. 2019. Market power in input markets: Theory and evidence from French manufacturing. Working Paper.

Nakamura, Emi, and Dawit Zerom. 2010. “Accounting for incomplete pass-through.” The Review of Economic Studies 77(3): 1192-1230.

Nigai, Sergey. 2017. "A tale of two tails: Productivity distribution and the gains from trade." Journal of International Economics 104: 44-62.

Nunn, Nathan. 2007. "Relationship-specificity, incomplete contracts, and the pattern of trade." The Quarterly Journal of Economics 122(2): 569-600.

Nunn, Nathan, and Daniel Trefler. 2014. "Domestic institutions as a source of comparative advantage." Handbook of International Economics. Vol. 4. Elsevier. 263-315.

Olley, G. Steven, and Ariel Pakes. 1992. The dynamics of productivity in the telecommunications equipment industry. National Bureau of Economic Research Working Paper No. w3977.

Olper, Alessandro, Lucia Pacca, and Daniele Curzi. 2014. "Trade, import competition and productivity growth in the food industry." Food Policy 49: 71-83.

Olper, Alessandro, Daniele Curzi, and Valentina Raimondi. 2017. "Imported intermediate inputs and firms' productivity growth: Evidence from the food industry." Journal of Agricultural Economics 68(1): 280-300. 
Pless, Jacquelyn, and Arthur A. van Benthem. 2019. "Pass-through as a test for market power: An application to solar subsidies." American Economic Journal: Applied Economics 11(4): 367-401.

Roberts, Mark J., and James R. Tybout. 1996. "Industrial evolution in developing countries: micro patterns of turnover, productivity, and market structure." New York : Published for the World Bank by Oxford University Press.

Roeger, Werner. 1995. "Can imperfect competition explain the difference between primal and dual productivity measures? Estimates for US manufacturing." Journal of political Economy 103(2): 316-330.

Rogers, Richard T. 2001. "Structural change in US food manufacturing, 1958-1997." Agribusiness 17(1): 3-32.

Ruan, Jun, and Munisamy Gopinath. 2008. "Global productivity distribution and trade liberalization: evidence from processed food industries." European Review of Agricultural Economics 35(4): 439-460.

Seok, Jun Ho, GwanSeon Kim, Michael R. Reed, and Soo-Eun Kim. 2018. "The impact of avian influenza on the Korean egg market: who benefited?". Journal of Policy Modeling, 40(1), 151-165.

Sexton, Richard J. 2013. "Market power, misconceptions, and modern agricultural markets." American Journal of Agricultural Economics 95(2): 209-219.

Topalova, Petia, and Amit Khandelwal. 2011. "Trade liberalization and firm productivity: The case of India." Review of economics and statistics 93(3): 995-1009.

Vancauteren, Mark. 2013. "EU harmonisation of regulations and mark-ups in the Dutch food industry." European Review of Agricultural Economics, 40(1): 163-189

Weinberger, Ariel. 2015. Markups and misallocation with trade and heterogeneous firms. Globalization and Monetary Policy Institute, Federal Reserve Bank of Dallas, Working Paper No.251.

Weldegebriel, Habtu Tadesse. 2004. "Imperfect price transmission: is market power really to blame?". Journal of Agricultural Economics 55(1): 101-114. 
Weyl, E. Glen, and Michal Fabinger. 2013. "Pass-through as an economic tool: Principles of incidence under imperfect competition.” Journal of Political Economy 121(3): 528-583.

Ye, Kunhui, Weisheng Lu, and Weiyan Jiang. 2009. "Concentration in the international construction market." Construction Management and Economics 27(12): 1197-1207. 
Figures and Tables

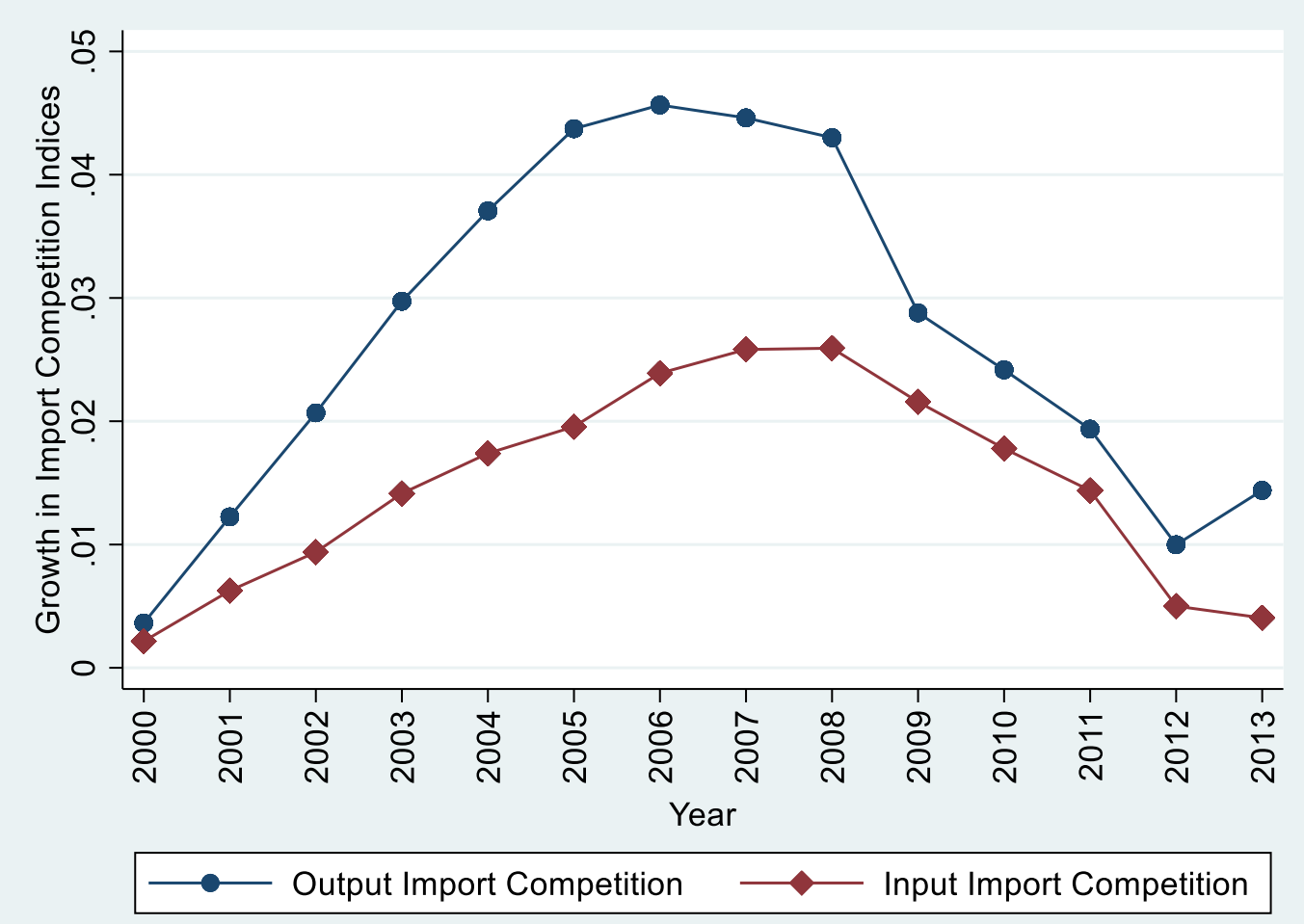

Figure 1: Output and input import competition, 2001-2013

Note: Trade data are taken from the EUROSTAT Comext Database. The import competition indices are constructed as defined in the main text. 


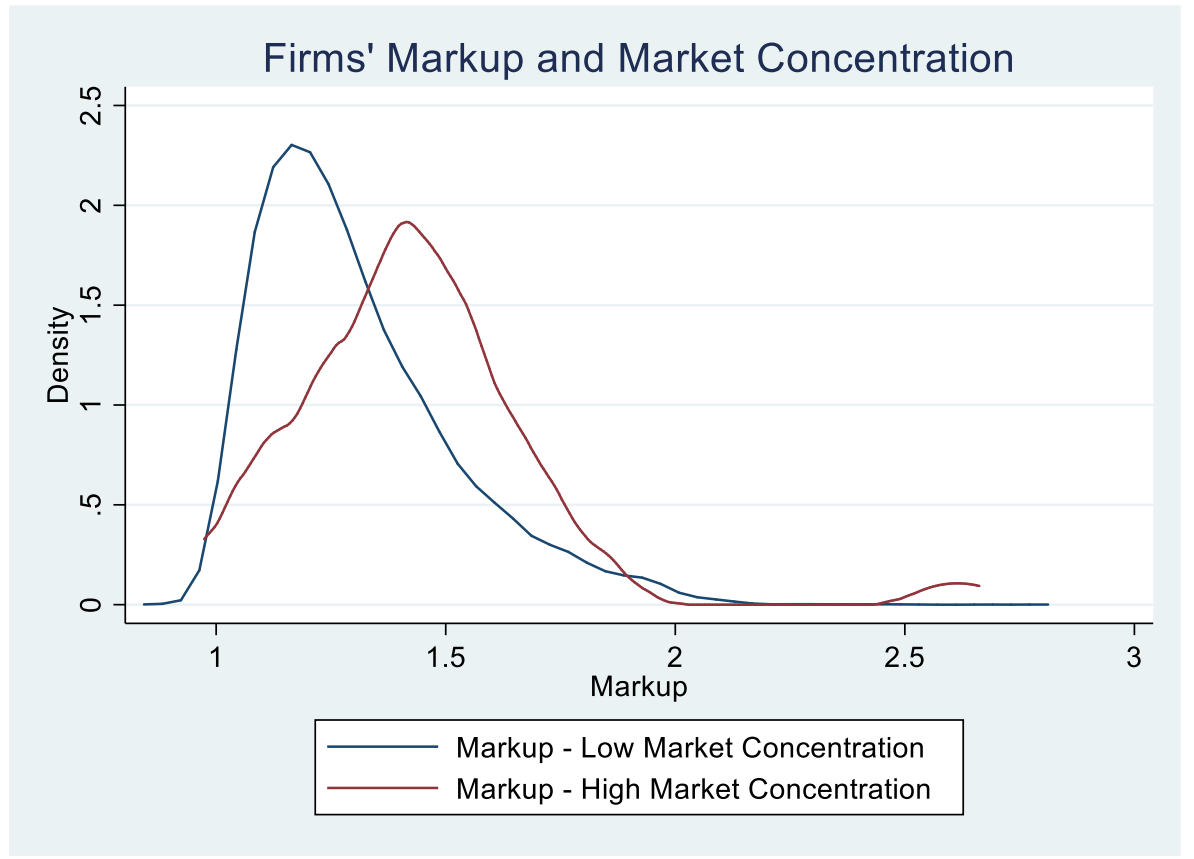

Figure 2 - Distribution of firm markups: low- vs. high-concentrated sectors

Note: The figure shows the distribution of markups in low- vs high-concentrated sectors, as defined by the Herfindahl Index. For further details on this distinction, see the main text. 
Table 1: Descriptive Statistics on Firm-Level Markups

\begin{tabular}{llcc}
\hline Nace 3 & Description & N. Obs. & $\begin{array}{c}\text { Markup TL } \\
\text { (median) }\end{array}$ \\
\hline & & & \\
101 & Meat Products & 7,217 & 1.23 \\
102 & Fish Products & 456 & 1.21 \\
103 & Fruit and Vegetables & 987 & 1.26 \\
104 & Oils and Fats & 280 & 1.31 \\
105 & Dairy products & 1,340 & 1.19 \\
106 & Grain mill and starch products & 15 & 1.18 \\
107 & Bakery and farinaceous product & 725 & 1.41 \\
108 & Other food products & 3,377 & 1.36 \\
109 & Prepared animal feeds & 721 & 1.14 \\
110 & Beverages & 1,691 & 1.30 \\
\hline
\end{tabular}

Note: All indices are computed and used in the analysis at the NACE 4-digit industry level but are shown in the table as the average at the NACE 3-digit level. For more details, see the main text. 
Table 2: Output and Input Import Competition and Firm-Level Markups

\begin{tabular}{|c|c|c|c|c|}
\hline \multirow[t]{3}{*}{ Dependent variable: $\Delta$ Log Markup (x100) } & (1) & (2) & (3) & (4) \\
\hline & OLS & $2 S L S$ & OLS & $2 S L S$ \\
\hline & Baseline & Baseline & $\begin{array}{l}\text { TOP } 10 \text { - } \\
\text { Markup }\end{array}$ & $\begin{array}{l}\text { Top 10- } \\
\text { Markup } \\
\end{array}$ \\
\hline$\Delta$ Output Import Competition $(x 100)$ & $\begin{array}{c}-0.136 * * * \\
(0.0437)\end{array}$ & $\begin{array}{c}-0.119 * \\
(0.0618)\end{array}$ & $\begin{array}{c}-0.182 * * * \\
(0.0456)\end{array}$ & $\begin{array}{c}-0.161^{* *} \\
(0.0683)\end{array}$ \\
\hline$\Delta$ Inputs Import Competition $(x 100)$ & $\begin{array}{c}0.235^{* * *} \\
(0.0682)\end{array}$ & $\begin{array}{l}0.248^{* *} \\
(0.102)\end{array}$ & $\begin{array}{l}0.192^{* * *} \\
(0.0712)\end{array}$ & $\begin{array}{c}0.213^{*} \\
(0.113)\end{array}$ \\
\hline$\triangle$ Output Import Competition - TOP $10(x 100)$ & & & $\begin{array}{c}0.708^{* * *} \\
(0.107)\end{array}$ & $\begin{array}{c}0.741 * * * \\
(0.155)\end{array}$ \\
\hline$\Delta$ Inputs Import Competition - TOP $10(x 100)$ & & & $\begin{array}{c}0.775^{* * *} \\
(0.247)\end{array}$ & $\begin{array}{c}1.189 * * * \\
(0.306)\end{array}$ \\
\hline Observations & 16809 & 15965 & 16809 & 15965 \\
\hline
\end{tabular}

Note: All regressions include a set of firm and year fixed effects. Robust standard errors clustered at the firm level are in parenthesis and are bootstrapped based on 50 replications. *, **, and *** indicate statistical significance at the $10 \%, 5 \%$ and $1 \%$ levels, respectively. The first stage of the 2SLS estimations presents Cragg-Donald Wald F statistics equal to 2023.47 and 3228.50 for the estimations in columns 2 and 4, respectively. 


\section{Table 3: Heterogeneous Effect of Import Competition on Firm-Level Markups}

\begin{tabular}{|c|c|c|c|c|c|c|}
\hline \multirow[t]{3}{*}{ Dependent variable: $\triangle$ Log Markup (x100) } & $(1)$ & $(2)$ & (3) & (4) & $(5)$ & (6) \\
\hline & \multicolumn{2}{|c|}{ Turnover } & \multicolumn{2}{|c|}{ Number of employees } & \multirow{2}{*}{ Exporters } & \multirow{2}{*}{ Non-Exporters } \\
\hline & Lower Size & Higher Size & Lower Size & Higher Size & & \\
\hline$\Delta$ Output Import Competition (x100) & $\begin{array}{c}-0.175^{*} \\
(0.102)\end{array}$ & $\begin{array}{l}-0.059 \\
(0.079)\end{array}$ & $\begin{array}{c}-0.158^{*} \\
(0.090)\end{array}$ & $\begin{array}{r}-0.061 \\
(0.099)\end{array}$ & $\begin{array}{l}-0.093 \\
(0.098)\end{array}$ & $\begin{array}{c}-0.138^{*} \\
(0.079)\end{array}$ \\
\hline$\Delta$ Inputs Import Competition $(x 100)$ & $\begin{array}{c}0.081 \\
(0.170)\end{array}$ & $\begin{array}{c}0.390 * * * \\
(0.109)\end{array}$ & $\begin{array}{c}0.099 \\
(0.205)\end{array}$ & $\begin{array}{c}0.311^{* * *} \\
(0.106)\end{array}$ & $\begin{array}{c}0.280 * * \\
(0.117)\end{array}$ & $\begin{array}{c}0.199 \\
(0.155)\end{array}$ \\
\hline Observations & \multicolumn{2}{|c|}{15965} & \multicolumn{2}{|c|}{15965} & \multicolumn{2}{|c|}{15965} \\
\hline
\end{tabular}

Note: The table presents the 2SLS estimations determined by running equation (3), estimating separate coefficients for lower- vs. higher-sized firms (columns 1 to 4 ) and exporters vs. non-exporters (columns 5 and 6). All regressions include a set of firm and year fixed effects. Robust standard errors clustered at the firm level are in parenthesis and are bootstrapped based on 50 replications. *, **, and *** indicate statistical significance at the $10 \%, 5 \%$ and $1 \%$ levels, respectively. The first stage of the 2SLS estimations presents Cragg-Donald Wald F statistics equal to 688.4 (estimates in columns 1 and 2), 655.2 (estimates in columns 3 and 4) and 1008.9 (estimates in columns 5 and 6). 


\section{Table 4: Import Competition and Markups: The Role of Market Concentration}

\begin{tabular}{|c|c|c|}
\hline \multirow[t]{3}{*}{ Dependent variable: $\triangle$ Log Markup (x100) } & $(1)$ & (2) \\
\hline & \multicolumn{2}{|c|}{ Herfindal Index } \\
\hline & $\begin{array}{c}\text { Low } \\
\text { Concentration }\end{array}$ & $\begin{array}{c}\text { High } \\
\text { Concentration }\end{array}$ \\
\hline$\Delta$ Output Import Competition (x100) & $\begin{array}{c}-0.157 * * * \\
(0.051)\end{array}$ & $\begin{array}{l}-2.566^{*} \\
(1.338)\end{array}$ \\
\hline$\Delta$ Input Import Competition (x100) & $\begin{array}{l}0.304^{* *} \\
(0.137)\end{array}$ & $\begin{array}{c}2.801 * * * \\
(1.075)\end{array}$ \\
\hline Observations & & 65 \\
\hline
\end{tabular}

Note: Table presents 2SLS estimations by running equation (3), estimating separate coefficients for low- vs. highconcentrated sectors. All the estimates include a set of firm and year fixed effects. Robust standard errors clustered at the firm level are in parenthesis and are bootstrapped based on 50 replications. The first stage of the 2SLS estimation presents a Cragg-Donald Wald $\mathrm{F}$ statistic equals to 1054 . *,**, and *** indicate statistical significance at the $10 \%, 5 \%$ and $1 \%$ levels, respectively.

\footnotetext{
${ }^{1}$ For example, as in many other countries worldwide, as an effect of trade integration of recent decades, the import competition in intermediate inputs and that in final goods have steadily increased in the food sector in France (see Figure 1).

${ }^{2}$ See e.g. Feenstra and Weinstein (2010) in the US; Levisohn (1993) in Turkey; Harrison (1994) in Cote d'Ivoire; Krishna and Mitra (1998) and Goldar and Aggarwal (2005) in India; Roberts and Tybout (1996) in Mexico, Colombia, Chile and Morocco. Feenstra (2018) recently restored the evidence on the pro-competitive effect of trade with reference to the US.

${ }^{3}$ Altomonte and Barattieri (2015) provide clear evidence for the pro-competitive effect of trade at aggregate level for Italian manufacturing firms, although heterogeneity across industries was also reported. Konings, Van Cayseele, and Warzynski (2001) show that in the Netherlands, higher price markups are associated with sectors with high import penetration, while in Belgium there has not been a significant effect on firm markups.

${ }^{4}$ See, e.g., Amiti and Konings (2007); Goldberg et al. (2010); Topalova and Khandelwal (2011); Dhyne et al. (2016); Olper, Curzi, and Raimondi (2017).

${ }_{5}^{5}$ This recent boost in exploring the different channels through which international trade might affect firm performance was also possible thanks to the increased availability of detailed firm production data combined with progress in econometric techniques, such as the new method developed by De Loecker and Warzynski (2012). Their method has been further extended, as in the case of De Loecker et al. (2016), where the authors exploit information on product-specific prices and quantities to derive estimates of product-level markups.

${ }^{6}$ Of course, the significant welfare implications of market power have been studied independently from the trade literature. Recent studies look at the evolution of markups over several decades and discuss the welfare implications
} 
and macroeconomic implications of the rise of market power (see De Loecker et al. (2020) for the US economy and De Loecker and Eeckhout (2018) for the economies of 134 countries).

${ }^{7}$ In addition to markup adjustments, the evidence from the literature suggest that other mechanisms may be at the root of the incomplete pass-through (Duso and Szuck, 2017), such as price rigidities (Goldberg and Hellerstein 2008; Nakamura and Zerom 2010), non-linear prices and vertical restraints (Bonnet et al. 2013), the demand curvature and market structure, as well as local fixed costs in oligopolistic markets.

${ }^{8}$ For example, the neo-Ricardian model of Eaton and Kortum (2002) or the monopolistic competition models of Krugman (1980), Melitz (2003), and Cheney (2008) were based on constant markups and constant elasticity of substitution (CES).

${ }^{9}$ Arkolakis et al. (2019) work in the context of gravity models featuring monopolistic competition, firm-level heterogeneity, and variable markups. These models are based on the assumption that firm-level productivity follows a (unbounded) Pareto distribution. The drawback of this approach is that it restricts the channels through which the pro-competitive effects may occur. In particular, they showed that under non-homothetic preference, the first (negative) force - incompletely pass-through - dominates the second (positive) force - reduced misallocation - so that gains from trade are strictly lower than those predicted by models with CES utility (and constant markups). In this respect, pro-competitive effects of trade are elusive. However, Feenstra (2018) and Feenstra and Weinstein (2017) by working with Pareto bounded productivity distribution, restore a role for the pro-competitive effects of trade. Yet, it turns out that neither the unbound nor the bounded Pareto distribution fit real data in a satisfactory manner (see Nigai 2017)

${ }^{10}$ Examples of studies within this strand of literature can be find in the industrial organization literature, when analyzing mergers (Jaffe and Weyl 2013), or to test the existence of market power within an industry (Pless et al. 2019), or to analyze tax incidence and distributional equity (e.g., Weyl and Fabinger 2013). In international economics, pass-through has been traditionally used when dealing with the effect of changes in exchange rates on the prices of imported products (e.g., Goldberg and Knetter 1997).

${ }^{11}$ Although it is common in many textbooks to indicate agricultural markets as perfectly competitive, the food chain is actually characterized by a successive or multi-stage oligopoly, where an oligopolistic sector sells its production to another oligopolistic sector, which eventually sells final products to consumers (McCorriston 2002; Sexton 2013; Lloyd 2017). This is because, although the agricultural market may be defined as competitive, the raw inputs are successively sold downstream to food processors and retailers, which are oligopolistic in their nature (McCorriston 2002).

12 There is also an alternative method, which is traditionally very popular in empirical IO literature, the so-called demand-approach (Berry, Levinsohn, and Pakes 1995). This method relies on behavioral assumptions for consumers and firms and requires a specific model of competition, e.g., Bertrand-Nash or Cournot competition. Due to these particular model assumptions and detailed data requirements, the application of this approach is constrained to specific markets (De Loecker et al. 2020).

${ }^{13}$ As noted by De Loecker et al. (2018): “while there still exist many measurement issues and associated econometric challenges [related to this methodology], to our knowledge there is no viable alternative to make progress" (p.4).

${ }^{14}$ To do that we follow the De Loecker (2013) estimation technique, which focuses on learning by exporting, and extend it to imports as well.

${ }^{15}$ Moreover, it is reasonable to assume that firms have ample room for the substitution of inputs, for example, employees replaced by capital while keeping output constant. Therefore, given that we are working with a firm level dataset, we can exclude the Leontief specification (De Loecker et al. 2016).

${ }^{16}$ Provided that the technological industry characteristics between two countries are comparable, such as the case of the US and EU food and drink processing industries, this method is a computationally straightforward solution to the lack of industry data for a country. See Nunn and Trefler (2014) for a general discussion about this method and Olper, Curzi, and Raimondi (2017) for its empirical application.

17 The BEA 'Use table' shows the use of commodities by intermediate and final users. 


\begin{abstract}
${ }^{18} \mathrm{We}$ are aware that import and export activities are likely to be correlated. To properly assess the role of exports in this framework, one would ideally need detailed information on the destination markets, which, however, are not available in our case.
\end{abstract}

${ }^{19}$ Ciccone and Papaioannou (2010) also refer to a second potential source of bias, which is an amplification bias that arises if the measure being used is systematically a better proxy for certain countries. This does not seem to be of much importance in our case, as France has US-like food industry technologies (see Olper, Curzi, and Raimondi 2017).

${ }^{20}$ Note that we have not included other EU countries because this choice could raise additional endogeneity concerns, as these countries are subject to the same EU policy.

${ }^{21}$ Note that Brandt et al. (2017) show that trade liberalization in the output market can also indirectly put upward pressure on markups because it may force less productive firms (with low markups) to leave the market and reallocate market shares towards more productive firms. This can result in an increase in the average markup. Our findings indicate this indirect effect, if anything, may soften the direct pro-competitive effect of output import competition, but they do not dominate.

${ }^{22}$ We compute a normalized Herfindahl index following Davies (1979) and Ye, Lu, and Jiang (2009). Starting from the Herfindahl index $H I=\sum_{i=1}^{n} S_{i}^{2}$, with $S_{i}$ being the share of sales of firm $i$ within a NACE 4 sub-sector, the normalized counterpart is computed as $H I^{N}=\frac{H I-1 / n}{1-1 / n}$.

${ }^{23}$ Note that, in our sample, the high-concentrated sectors are those with $H I$ values higher than 2,200. It is common practice to define high-concentrated sectors as those having a $H I$ greater than 2,500, while those having a $H I$ value between 1,500 and 2,500 are considered moderately concentrated. Sectors showing a $H I$ lower than 1,500 are usually considered to be low concentrated sectors. The average $H I$ in our sample is 730 , while the median value is 440 . These low $H I$ values reflect the high presence of small firms in many sectors of the French food industry.

${ }^{24}$ In this paper, we use the revised classification of NACE Rev. 2, which was adopted at the end of 2006. Following this classification, the food industry belongs to the following code categories: (a) manufacture of food products, (C 10) including the processing of the products of agriculture, forestry and fishing into food for humans or animals, and includes the production of various intermediate products that are not directly food or feed products; and (b) the manufacture of beverages (C11), such as non-alcoholic beverages and mineral water, manufacture of alcoholic beverages mainly through fermentation, beer and wine, and the manufacture of distilled alcoholic beverages.

25 The turnover and material costs were deflated using the gross product output deflators and intermediate input deflators from OECD STAN. For labor costs, we use a labor cost deflator taken from the European Central Bank, while firms' total assets were deflated using the gross fixed capital formation deflator from Eurostat.

${ }^{26}$ By using an unbalanced dataset, we implicitly allow for firm entry and exit. Moreover, we consider the TL specification, which, although not directly relevant to address sample selection bias, takes into account the variability in the firm size.

${ }^{27}$ Note that when implementing our econometric routine, the analytical sample is further reduced due to some missing values.

${ }^{28}$ Note that the BEA codes are linked with the North American Industry Classification System (NAICS) code classification. To make this data available for our analysis, we use the corresponding tables to convert them to the NACE codes.

${ }^{29}$ To give an indication of the extent to which the domestic demand is satisfied by imports, in the Additional Material section we plot the evolution of the Output and Input Import Competition indices by considering imports in level rather than in growth (Figure B.7). The initial value of the output import competition index is approximately $26 \%$, while it is approximately $20 \%$ for inputs. Both these indexes show similar patterns, with a large proportion of the domestic demand for final goods and intermediates inputs that is satisfied by imports. It is worth noting that the incidence of imports in intermediate inputs almost doubles over the considered period, while the incidence of output import competition more than doubles in the same period.

${ }^{30}$ The summary statistics on the main variables used in the estimations of the effect of output and input import competition on firm-level markups throughout the paper are reporter in Table D.1 of the Additional Material Section. 
In Table D.2, instead, we report the estimates under a CD technology. The results under the CD technology are qualitatively similar to the ones under TL.

${ }^{31}$ Note that the direction and magnitude of the effects of output and input import competition remain virtually the same when they are estimated individually in two different regressions.

32 Note that, as suggested by De Loecker and Warzynski (2012), as we estimate markups using revenue data, the level of markup may be biased by the lack of information on differences in prices across firms. However, this potential bias does not affect the correlation of markups with firm-level characteristics or the change in markups over time.

${ }^{33}$ Note that the results presented in Table 2 concerning top-10 markup firms are qualitatively and quantitatively similar if we consider firms belonging to the 95th percentile of industries' markup distribution.

${ }^{34}$ De Loecker and Eeckhout (2018) suggest that an increase in markups of firms belonging to the upper tail of the markup distribution may be explained by the following three main components: $i$. a change in markup itself; $i i$. firms' entry and exit dynamics; and iii. a reallocation of economic activities towards higher markup firms. This last point has been highlighted by Autor et al. (2020) and De Loecker et al. (2020) in the United State (US). Autor et al. (2020) call this phenomenon "the rise of superstar firms", according to which, among various effects, the higher competition induced by globalization has led several firms to exit the market and their economic activity to be reallocated from low to high markup firms.

${ }^{35}$ Namely, in the presence of fiercer competition, a few firms are able to exploit their market power to increase their market share. Such a reduction in the number of competitors leads these firms to increase the markups (De Loecker et al. 2020).

${ }^{36}$ Evidence of reallocation of market share following trade liberalization in the food industry leading to an increase in sectoral Total Factor Productivity is shown in Ruan and Gopinath (2008) and Olper, Pacca, and Curzi (2014). Similarly, Aleksanyan and Huiban (2016) show that exits from the market in the French food sectors have been massively concentrated among less competitive (low-productive) food firms after 2010.

${ }^{37}$ Evidence of similar pass-back dynamics have been documented in the literature, for instance, in Lloyd et al.'s (2006) study, which deals with the effect of BSE on beef prices, and Seok et al.'s (2018) work, which considers the case of the Avian Influenza on eggs market, or in the work of Lloyd et al. (2009), which considers different sectors in the UK food chain.

${ }^{38}$ Note that we also complement the analysis presented in this section with an empirical assessment of the impact of output and input import competition on the (sectoral) markup dispersion. Following Lu and Yu (2015), we measure the markup dispersion using a Theil Index, one of the most widely used measures of entropy. An in depth discussion of the mechanisms driving the relationship between import competition and markup dispersion, as well as a detailed description of the index used for this analysis and the main results, are presented in Section $\mathrm{C}$ of the Additional Material.

${ }^{39}$ Note that we consider as exporters those firms exporting more than half time within the considered period. In doing, that we do not consider as such occasionally exporting firms.

${ }^{40}$ Evidence of this mechanism can be found theoretically in the Melitz and Ottaviano (2008) model and empirically in De Loecker and Warzynski (2013) and Bellone et al. (2016).

${ }^{41}$ Note that, as we show in Section C of the Additional Material section, our results are robust to the use of a Lerner Index as an alternative measure of market competition (see Table C.5).

${ }^{42}$ Edmond, Midrigan, and Xu (2015), analyzing Taiwanese data, suggest that this effect is due to the fact that more concentrated domestic sectors are those where import penetration grows more, where the (distorted) competitive setting is more affected when opening up trade.

${ }^{43}$ The authors suggest that in more concentrated markets, a few firms exploit the reduction of input costs while keeping their price high and therefore consistently increase their markups.

${ }^{44}$ It is worth noting that other issues may affect our results. For instance, firms' offshoring or outsourcing activities are likely to have an influence on the formation of firm markups. However, the lack of any information on these types of activities prevents our analysis from making any assessment of the extent to which they can affect firm markups. 